\title{
Expert assessment of security of arable soils of Ukraine with macroelements of plant nutrition
}

\author{
A. Khrystenko, \\ Candidate of Agricultural Sciences \\ National Scientific Center «Institute of Soil Science and Agrochemistry named after O.N. \\ Sokolovsky»
}

The purpose. To give expert assessment of natural fertility of arable soils of Ukraine concerning their security with macroelements of plant nutrition on the basis of modern methodical and theoretical development. Methods. Statistical-mathematical analysis of materials of automized data bank of agrochemical properties of soils. Theoretical basis of probes is the concept considering edaphic systems as open polymorphic and polycomponent thermodynamic systems. Results. Analysis of materials SE «Institute of protection of soils of Ukraine» has displayed availability of factors preventing deriving exact state assessment of fertility of soils concerning their security with macroelements of plant nutrition. It is connected to imperfection of methods of edaphic diagnostics and methodology of realization of agrochemical certification of lands. The soil factors preventing deriving objective state assessment of fertility are also specified. Conclusions. Now the average content of nitrogen, phosphorus and potassium in soils of Ukraine matches to means of their security with these nutrients. Therefore on all natural soils of the country it is impossible to receive stable heavy yields of crops without application of conforming doses of organic and mineral fertilizers.

Key words: arable soils, movable joints, nitrogen, phosphorus, potassium, assessment of fertility.

The purpose of agrochemical certification of agricultural lands is to obtain reliable estimates of their fertility, monitoring the dynamics of indicators of fertility and contamination. Unfortunately, these features because of different reasons are not carried out in full. Previously the author has been proved that all acid techniques are related to "hard" methods. Their disadvantage is the high probability of distortion in the results of chemical analysis under various soil factors [3]. Ukraine soils contain different amounts of minerals of apatite, feldspar or three-layered aluminosilicate.

Most phosphorus or potassium contained in these minerals, are not directly accessible for plants. But they have partially extracted by solutions of strong acids, in particular $0,5 \mathrm{~m} \mathrm{CH}_{3} \mathrm{COOH}$ or $0.2 \mathrm{n} \mathrm{HCl}$ (methods Chirikov and Kirsanov). These factors (and certain $\mathrm{pH}$ soil solution) by using state standards of the USSR created the appearance of different (from very low to very high) natural supply of arable soil of Ukraine by these nutrition elements.

Using these methods allows us to get an objective assessment of the nutrition state of soils with certain properties. Namely those composition and properties are close to the properties of soils, on which it was conducted research on the development of groups of phosphorus or potassium availability. For example, for the method Kirsanov the group was developed on podzolic soils of Russia that have a value $\mathrm{pH}_{\mathrm{Kc}}$ within $4,5-$ 6,8 fraction content Ca-P - 80-100 mg $\mathrm{P}_{2} \mathrm{O}_{5} / \mathrm{kg}$ soil (by Chang-Jackson) and physical clay content within 44$48 \%$. Using this method in soils with different properties leads to disruption of the main rules of the experiment - the principle of a single-difference.

Standardization Technical Committee (TC 142 "Soil Science"), which was created based on the NSC ISSAR, developed more than 300 regulations [1]. Among them 10 are applicable national standards of Ukraine and 3 approved standards for methods of determining the nitrogen, phosphorus or potassium in soils. The proposed system DSTU, overall, meets modern requirements because it is partially harmonized with international-standard documents. In addition, by its development the modern theories were used. 
However, the experience of using these standards showed the presence of a number of problems. For example, using amendments (described in DSTU as tables), depending on the properties of soils, slightly increases the precision of diagnostics. But it can not solve the problem as a whole.

In addition, there are a number of organizational and technical problems. For example, the need to obtain more information about content of physical clay and soil $\mathrm{pH}$. It is necessary to study and work out the possibility of phasing out of the using "hard" methods. This is done in most countries.

In addition, in the DSTU are given not errors of content $\mathrm{P}_{2} \mathrm{O}_{5}$ or $\mathrm{K}_{2} \mathrm{O}$, but standards of definition error. This was done by analogy with our technical standards. But it turned out that this form of presentation of information is not good, because it complicates the processing. This shortcoming was corrected only by the design of last project of DSTU (Maslova method).

The practice of SI "Institute for Soil Protection in Ukraine" has also shown the existence of problems on the methodology of agrochemical certification of land. The first problem - slow transition of the institution to conduct chemical analyzes of soil samples according to the National Standards of Ukraine. Second problem - imperfection of survey methodology, namely the withdrawal during the last years from examination the least fertile soils.

First of all, it's soil of light particle size distribution. Thus, in the years 1966-1970 area of arable land survey was 30.9 million hectares, but in 2006-2010 - a total of 24.8 million hectares.

Imperfection of methodology led to the phenomenon of "involuntary" increasing $\mathrm{P}_{2} \mathrm{O}_{5}$ or $\mathrm{K}_{2} \mathrm{O}$ content in soils (marked in a number of publications). Under a sharply negative balance of elements of plant nutrition in land it is impossible. For this reason the assessment of soil fertility in Ukraine regarding phosphorus and potassium is not entirely objective.

National security is closely related to the conservation of soils. The lack of objective information about their nutritious condition leads to wrong management decisions, development of incorrect strategies and tactics of fertilizer application.

Research purpose. Provide expertise assessment of natural fertility of arable soils of Ukraine concerning macro elements of plant nutrition based on modern methodological and theoretical developments.

Research methods. Statistical analysis and synthesis of materials for automatic bank of soil agrochemical properties data (based on Access database 98). The information bank contains analyzes data about 2,000 samples of different soils. The theoretical basis of research is the concept that considers soil system as open polymorphic and multicomponent thermodynamic systems [2].

Research results. As it was established earlier by the author, level of dynamical balance in arable soils, expressed as the content of available phosphorus, meets the following values $\left(\mathrm{P}_{2} \mathrm{O}_{5} / \mathrm{kg}\right.$ soil): $50,0 \pm 5,0$ by Chirikov, $50,0 \pm 5,0$ by Kirsanov, $16,0 \pm 2,0$ by Machyhin.

The level of dynamic equilibrium of potassium system of arable soils meets the following values $\left(\mathrm{K}_{2} \mathrm{O} / \mathrm{kg}\right.$ soil): $60,0 \pm 15,0$ by Chirikov, $100,0 \pm 20,0$ by Kirsanov, $150,0 \pm 25,0$ by Machyhin [4] . That is level of dynamic equilibrium of these systems is on the verge low and average values of phosphorus availability within the average values of potassium availability.

According to the I survey tour the average content of available phosphorus in Polissya zone was by the Kirsanov method-63,0 mg $\mathrm{P}_{2} \mathrm{O}_{5}$ and available potassium-64,0 $\mathrm{mg} \mathrm{K}_{2} \mathrm{O} / \mathrm{kg}$ soil (medium availability). This content of nutritious substances in soils (including low doses of fertilizers that were used at that time), we can take for the natural level. Average values of these indicators were close to the level of dynamic equilibrium.

Thus the average content of mobile phosphorus and potassium was significantly differed in areas of this zone. For phosphorus it was ranged from $36-38 \mathrm{mg} \mathrm{P}_{2} \mathrm{O}_{5} / \mathrm{kg}$ in Ivano-Frankivsk and Zakarpattya regions to 73-102 mg $\mathrm{P}_{2} \mathrm{O}_{5} / \mathrm{kg}$ in Chernihiv and Rivne regions. For potassium: $\mathrm{K}_{2} \mathrm{O}$ content was ranged from 48-59 $\mathrm{mg} / \mathrm{kg}$ in Zhytomyr and Chernihiv regions to $136 \mathrm{mg} / \mathrm{kg}$ of soil in the Transcarpathian region.

The soils of Polissya are usually characterized by easy particle size (less than $20 \%$ of physical clay). In this regard, they contain much less apatite compounds (except chernozem soils in loess rocks of Rivne region) and potassium containing minerals. Therefore the use of taken communities of availability of these soils by phosphorus or potassium led to an artificial lowering evaluation of their fertility. 
Strongly acidic $\left(\mathrm{pH}_{\mathrm{kc}}<4,5\right)$ podzolic soils inherent in highly activity of sesqui oxides of iron and aluminum. Processing of such soils with solutions of acids (including $0,2 \mathrm{n} \mathrm{HCl}$ ) increases the positive charge of colloidal particles, leading to an increase in secondary absorption of anions of phosphoric acid in the analysis. And as a result, leads to a significant underestimation of obtained data. Illusion of low natural availability of arable soils of Ivano-Frankivsk and Zakarpattya regions with available phosphorus is due the influence of this factor (increased acidity of soils).

Visibility of natural differences in the content of available potassium compounds in soils of Polissya zone (from $48 \mathrm{mg} \mathrm{K}_{2} \mathrm{O} / \mathrm{kg}$ of soil - Zhytomyr region, up to $136 \mathrm{mg} \mathrm{K} \mathrm{K}_{2} \mathrm{O} / \mathrm{kg}$ of soil - Transcarpathian region) is caused by a significant difference in the size distribution of soils in this zone.

Chemical analysis of soils to determine the content of available phosphorus and potassium in the ForestSteppe zone to 2005 was conducted in accordance with GOST 26204-91 (method by Chirykov). According to the first round of survey the average content of mobile phosphorus in the plow layer of soils in this zone amounted to $81 \mathrm{mg} \mathrm{P}_{2} \mathrm{O}_{5}$ and available potassium $-87 \mathrm{mg} \mathrm{K}{ }_{2} \mathrm{O} / \mathrm{kg}$ soil. That is the weighted average of these indexes (as phosphorus and potassium) slightly exceeded the level of dynamic equilibrium.

Thus the average content of available phosphorus and potassium was very different in areas of the zone. For phosphorus it ranged from 37-60 mg $\mathrm{P}_{2} \mathrm{O}_{5}$ in soils of Chernivtsi and Ternopil regions to 102-105 $\mathrm{mg} \mathrm{P}_{2} \mathrm{O}_{5}$ $/ \mathrm{kg}$ - in Cherkasy and Sumy regions. That is from very low to high availability. $\mathrm{K}_{2} \mathrm{O}$ content ranged from 45$50 \mathrm{mg} / \mathrm{kg}$ (in Kiev and Khmelnytsky regions) to $123 \mathrm{mg} / \mathrm{kg}$ in the Kharkiv region. That is from medium to high availability with available potassium.

It was found that visibility of low phosphorus availability of arable soils in Chernivtsi region - $37 \mathrm{mg} \mathrm{P}_{2} \mathrm{O}_{5}$ / $\mathrm{kg}$-is caused by the negative impact of the increased acidity of podzolic brown soils on the result of chemical analysis. The low content of mobile phosphorus in soils of Ternopil region - $60 \mathrm{mg} \mathrm{P}_{2} \mathrm{O}_{5} / \mathrm{kg}$-is explained by the predominance of podzolic soils in soil cover (dark gray podzolic and chernozem podzolic), which are characterized by low content of apatite.

Visibility of good availability of phosphorus by soil in Cherkasy and Sumy regions is due to the high content of apatite-like compounds in chernozem typical on loess breeds. Difference visibility in the of soil potassium state of different regions is caused by the difference in their size distribution. In Kiev and Khmelnytsky regions podzolic soils of light size distribution.

In the Kharkiv region, by contrast, it is dominated soils of turf type of soil formation of heavy size distribution, which determines high content of vinegar-soluble potassium. Most of this potassium can hardly be called available potassium.

Chemical analysis of soils to determine mobile compounds of phosphorus and potassium in most areas of the Steppe zone was carried out in accordance with GOST 26204-91 (method Chirykov). In the Kherson region and Crimea it was carried out by the method Machyhin. According to the I tour of survey the average content of available phosphorus in the plow layer of soils of this area amounted to $67 \mathrm{mg} \mathrm{P}_{2} \mathrm{O}_{5}$ and available potassium - $126 \mathrm{mg} \mathrm{K} \mathrm{K}_{2} \mathrm{O} / \mathrm{kg}$ of soil (by Chirykov). That is the average value of these indicators slightly exceeded the level of dynamic equilibrium by phosphorus and significantly - by potassium. Soil-formative breed on the main area of Steppe zone is loess and loess loams. This determines the visibility of welfare on soil availability by phosphorus and potassium.

Soils of Donetsk region are characterized by the relatively low content of $\mathrm{P}_{2} \mathrm{O}_{5}-50 \mathrm{mg} / \mathrm{kg}$. This is due to the fact that in this area there are common chernozems ordinary on eluvium of clay slates containing apatite less than soils in loess breeds. The lowest $\mathrm{P}_{2} \mathrm{O}_{5}$ content was observed in soils of Crimea - $13 \mathrm{mg} / \mathrm{kg}$ (by Machyhin). As it was determined earlier, using this method in soils with alkaline reaction leads to a significant artificial underestimation of data that are collected. As for potassium, its number is almost the same artificially increased in most soils of this area.

It is known that the systematic application of fertilizers increases the availability of soils by available forms of nutrients. This phenomenon was observed during the years of the so-called intensive chemicalization.

According to the latest round of agrochemical survey the availability of Ukrainian soils by phosphorus and potassium, despite decreasing trend, is characterized as increasing one (Table). This tour was held under a sharply negative balance of nutrients in agriculture. 
Average content of available phosphorus and potassium compounds in the soils of Ukraine (according to the SI "Institute for Soil Protection of Ukraine")

\begin{tabular}{|l|l|l|l|l|l|l|}
\hline Year of survey & $\begin{array}{l}\text { Area of survey } \\
\mathrm{mln} . \mathrm{ha}\end{array}$ & $\begin{array}{l}\text { Application with fertilizers, } \\
\mathrm{kg} / \mathrm{ha}\end{array}$ & $\begin{array}{l}\text { Content of } \\
\mathrm{P}_{2} \mathrm{O}_{5}, \\
\mathrm{mg} / \mathrm{kg}\end{array}$ & $\begin{array}{l}\text { Content of } \\
\mathrm{K}_{2} \mathrm{O}, \\
\mathrm{ng} / \mathrm{kg}\end{array}$ \\
\cline { 3 - 6 } & & $\mathrm{P}_{2} \mathrm{O}_{5}$ & $\mathrm{~K}_{2} \mathrm{O}$ & 71 & 98 \\
\hline $1966-1970$ & 30,9 & 14 & 12 & 106 & 113 \\
\hline $1986-1990$ & 29,4 & 41 & 42 & 100 & 112 \\
\hline $2006-2010$ & 24,8 & 10 & 7 & & \\
\hline
\end{tabular}

Unfortunately, this assessment of soil fertility is significantly overstated. As already mentioned, the main reason for the lack of the expected significant reduction of $\mathrm{P}_{2} \mathrm{O}_{5}$ and $\mathrm{K}_{2} \mathrm{O}$ in the soils in recent years is imperfect methodology summarizing the results of the survey.

In addition, application of fertilizers not only increases the availability of soils by nutrients of plants, but also transfers a phosphate or potassium soil system in the energetically unfavorable nonequilibrium state. Consequently, after stopping fertilization available compounds content of nutrients in the soil will decrease to baseline. According to the second law of thermodynamics a dynamic equilibrium level is consistent physical and chemical conditions that exist on the planet. Moreover, the duration of the process is determined, above all, by the number of remaining fertilizer compound.

For example, according to the received mathematical model average decrease of $\mathrm{P}_{2} \mathrm{O}_{5}$ content on artificial phosphate background an (P1800) was constituted in the first 10 years of $5.5 \mathrm{mg} / \mathrm{kg}$ (Chirykov method). During 30 years intensity of decreasing was slowed: $4,1 \mathrm{mg} \mathrm{P}_{2} \mathrm{O}_{5} / \mathrm{kg}$ of soil for 1 year. Soil was chernozem typical hardy loamy.

The intensity of the average decrease of $\mathrm{K}_{2} \mathrm{O} / \mathrm{kg}$ content (K1200background) was slightly higher than the phosphorus and was $5,2 \mathrm{mg} \mathrm{K} \mathrm{K}_{2} \mathrm{O} / \mathrm{kg}$. Decreasing potassium level of soil from $140 \mathrm{mg} \mathrm{K} 2 \mathrm{O} / \mathrm{kg}$ (K1200 background) to the original level $-80 \mathrm{mg} \mathrm{K} \mathrm{K}_{2} \mathrm{O} / \mathrm{kg}$ of soil - was during 11 years old.

According to established patterns (in terms of the extensive use of soils) average content of phosphorus and potassium in Ukraine should correspond to the level of dynamic equilibrium. But as fertilizers were applied, this, at least relative to phosphorus didn't happen. In recent years there is a gradual increase in the use of phosphate fertilizers - from $2 \mathrm{~kg} / \mathrm{ha}$ in 2000 to $13 \mathrm{~kg} / \mathrm{ha}$ in 2014 .

It was found that on the fields, which are characterized by the presence of residual phosphates, application even small doses of phosphate fertilizers (10-15 $\mathrm{kg} \mathrm{P}_{2} \mathrm{O}_{5} / \mathrm{ha}$ ) significantly slowed the fall of phosphate level of soils. Moreover, in this case, the doses of fertilizers can stabilize phosphorus content at a level that exceeds the natural at $20-25 \mathrm{mg} \mathrm{P}_{2} \mathrm{O}_{5} / \mathrm{kg}$ of soil. That, perhaps, is observed now in the soils of Ukraine. In comparison, for optimal soil phosphate levels it should be increased the natural level at $60-100 \mathrm{mg} \mathrm{P}_{2} \mathrm{O}_{5} / \mathrm{kg}$ of soil (depending on the growing crops).

As for nitrogen state of soil, practically all nitrogen in the soil is in not hydrolyzed organic compounds, i.e. soluble form. Regardless of the type of soil, humus content or total nitrogen, mineral nitrogen fraction is usually less than $1 \%$. The main reason for the low natural supply of the majority of arable soils of Ukraine (from sod-podzolic to chernozem) by available nitrogen is low content of detritus and newly organic matter. The reason: almost absence of organic fertilizers and perennial legumes.

Increased or high content of mineral nitrogen (nitrate and ammonium) actually is observed in three cases: by application of high doses of organic and nitrogen fertilizers; after black steam; after plowing layer of perennial legumes. And, as a rule, such an increase is observed not longer than 4-6 months.

\section{Conclusions.}

Analysis of SI "Institute for Soil Protection of Ukraine" has shown problems regarding assessment accuracy of soil fertility relatively macroelements of plants. The reason is imperfection of methods for soil diagnosis and methodology of agrochemical certification of lands. This necessitates providing expertise assessment of natural fertility of arable soils of Ukraine. 
Based on the data that were obtained using a national system of soil diagnosis, and established patterns, it can be argued the following. Currently, average content of available nitrogen, phosphorus and potassium in arable soils of Ukraine corresponds the average value of availability by these nutrients. Therefore, to obtain high yields of crops it is necessary to apply fertilizers on all not cultivated soils of Ukraine.

\section{Bibliography}

1. Lazebna M.le. Systema normatyvnoho zabezpechennia yakosti ta okhorony gruntiv: avtoref. dys. na zdobuttia nauk. stupenia kand. s.-h. nauk: spets. 06.01 .03 «Ahrogruntoznavstvo ta ahrofizyka»/M.le. Lazebna. -Kh., 2011. - $20 \mathrm{~s}$.

2. Makkelvy V.E. Fosfor v okruzhaiushchei srede/V.E. Makkelvy; pod red. Э. Hryffyta y dr. - M.:Myr, 1977. - S. 24-46.

3. Prokoshev V.V. Teoretycheskye y praktycheskye aspektы yssledovanyia nekotorbkh metodov opredelenyia kalyia v pochve/V.V. Prokoshev, V.V. Nosov//Pochva - udobrenye - plodorodye. — Mynsk: BelNYYPA, 2000. - S. 92-98.

4. Smahyn A.V. Byoheotsenolohycheskoe napravlenye v pochvovedenyy/A.V. Smahyn//Pochvovedenye. - 1996. - № 3. - C. 298-309.

5. Trofymov S.la. Funktsyonyrovanye pochv $v$ byoheotsenozakh:podkhodы k opysanyiu y analyzu/S.la. Trofymov, S.N. Sedov//Pochvovedenye. — 1997. — № 6. - S. 770-778.

6. Khrystenko A.A. Yspolzovanye natsyonalnыkh standartov dlia dyahnostyky azotnoho, fosfatnoho y kalyinoho sostoianyia pochv Ukraynd/A.A. Khrystenko//Ahrokhymyia. — 2014. — № 7. — S. 75-83.

7. Khrystenko A.O. Rukhomist «rukhomykh» elementiv zhyvlennia roslyn u grunti/A.O. Khrystenko//Visn. ahrar. nauky. - 2009. — № 8. - S. 16-20.

8. Changes in gene expression in Arabidop-sis shoots during phosphate starvation and potential for developing smart plants/J.P. Hammond, M.J. Bennett, H.C. Bowen et al.//Plant Physiol. — 2003. — V. 132. — № 2. - P. 578-596.

9. Khristenko A.A. Diagnosis accuracy improvement of the phosphate status of Ukrainian soils/A.A. Khristenko, S.E. Ivanova//Better crops. - 2012. - V. 96. — № 2. - R. 5-7.

10. Leal J.E. Evaluation of available $P$ with different extractants on Guatemalan soils/J.E. Leal, M.E. Summer, L.T. West//Commun. Soil Sci. and Plant Anal. —1994. — V. 25. — № 9-10. — P. 1161-1196. 